DOI: $10.15290 /$ pnib.2020.11

ks. Adam Skreczko

\title{
Człowiek, małżeństwo i rodzina według Arcybiskupa Edwarda Ozorowskiego
}

Dorobek naukowy abp. prof. dr. hab. Edwarda Ozorowskiego jest imponujący i wielowątkowy. Już liczba publikacji o różnej konotacji naukowej - ponad 1200 pozycji, świadczyć może o ogromie włożonego wysiłku. Znaleźć w jego dorobku można książki, artykuły, recenzje, hasła z zakresu nauk teologicznych, hasła osobowe, opublikowane przemówienia, odezwy administracyjne i inne. Podejmując próbę ukazania trzech ważnych zagadnień poruszanych w tych publikacjach: osoby, małżeństwa i rodziny, zdaję sobie sprawę z tego, że będzie to zaledwie przyczynek do dalszych, pogłębionych analiz.

Bogata działalność naukowo-dydaktyczna prof. abp. E. Ozorowskiego, wyrażona w licznych publikacjach i na wykładach prowadzonych w wielu ośrodkach uniwersyteckich w kraju i za granicą, skłaniają do uważnej analizy jego dorobku, aby dostrzec oryginalność myśli, wydobyć całe jej bogactwo płynące z pracy naukowej i dydaktycznej, realizowanej na przestrzeni ponad czterdziestu lat.

\section{Człowiek}

Znaczący jest wkład teologiczny abp. Ozorowskiego szczególnie w eklezjologię i tematykę z nią integralnie związaną, czyli chrystologię, mariologię, naukę o sakramentach. Szukając oryginalności i nowatorstwa myśli antropologicznej, a zwłaszcza dotyczącej małżeństwa i rodzinny u naszego Autora, należy ją rozpatrywać w powiązaniu z wymienionymi tu naukami teologicznymi, którymi głównie się zajmował.

Zaczynając od Kościoła, któremu Autor poświecił książkę: Kościót. Zarys eklezjologii katolickiej (Wrocław 1984), to widzi w nim nie tylko wspólnotę wierzących, ale jej element strukturalny i operatywny ${ }^{1}$. W Kościele, jako wybranym przez Boga "narzędziu” Zbawienia, znajdują się istotne elementy życia nadprzyrodzonego: Słowo Boże i sakramenty, a wśród nich Eucharystia ${ }^{2}$. To Eucharystia jako źródła życia nadprzyrodzonego jest tym "ziarnem”, które wraz

Podobnie ujmuje Kościół w czytankach majowych: Piotrowe dziedzictwo. Rozważania majowe, Białystok 1991.

2 Por. E. Ozorowski, Eucharystia w nauce i praktyce Kościoła Katolickiego, Poznań 1990. 
z realizowaniem przez człowieka wezwaniem Stwórcy prowadzi stworzenie do swego celu, jakim jest „odtwarzanie obrazu Boga”. I ta rzeczywistość realizuje się szczególnie w życiu świętych ${ }^{3}$.

Wartość tego dyskursu jest nie tylko teologiczna, ale też egzystencjalna. Chodzi w nim bowiem nie o teoretyczne jedynie odkrywanie natury Boga, ale o Jego relacje do świata. W tych relacjach ważny jest stosunek Boga do ludzkiego cierpienia, które stawia człowieka, także wierzącego, wobec pytania: jak można pogodzić istnienie wielowymiarowego zła z istnieniem Boga, który z natury swej powinien być nieskończenie dobry i wszechmocny? Jak można wierzyć, że Bóg jest Ojcem pragnącym dobra dla swojego stworzenia, podczas gdy dochodzi do niszczących człowieka i jego otoczenie kataklizmów naturalnych, czy do różnego typu przemocy wobec osób bezbronnych?

Podejmując różne próby dania odpowiedzi na te pytania podaje, że wiara chrześcijańska opiera się na przekonaniu, iż objawienie prawdziwego oblicza Boga osiąga swój szczyt w wydarzeniu Jezusa Chrystusa, w tym również „ojcowskie" oblicze Boga.

Pisząc na te tematy, nasz Autor stosunkowo często podejmuje tematykę antropologiczną i ukazuje piękno człowieka stworzonego na "obraz i podobieństwo Boga".

W jego twórczości dostrzec można konsekwentną logikę wiary i rozumu. Skoro bowiem chrześcijanin przyjmuje w wierze, że człowiek został stworzony przez Boga na Jego „obraz", a tym „obrazem” jest Chrystus, to logiczny jest wniosek, że człowieka nie można zrozumieć w pełni bez odwołania się do Chrystusa.

Takie podejście dało naszemu Autorowi podstawy do ukazania personalizmu chrześcijańskiego. Tak oto pisze:

Personalizm chrześcijański bierze swój początek w Jezusie Chrystusie. Pojawił się na arenie dziejów jako Dobra Nowina - Ewangelia. (...) W Chrystusie Bóg tak ściśle zjednoczył się z człowiekiem, że to zjednoczenie stało się unią hipostatyczną. Wszystko, co ludzkie aż po najniższe warstwy cielesności, zostało przeniknięte Boskim Logosem (por. J 1,14). W Chrystusie zaś, z Nim i przez Niego, wszyscy otrzymali zaproszenie do takiego zjednoczenia z Bogiem. (...) Personalizm chrześcijański dopiero ukazuje właściwy cel ludzkiego życia, którym jest zjednoczenie z Bogiem w Trójcy Świętej Jedynym w komunii osób $b^{4}$.

Kontynuując tę myśl, Biskup Ozorowski stwierdza, że „rozumienie człowieka, jakie daje Chrystus, było i jest siłą napędową Kościoła. Nie zawsze potrafiło ono przebić się przez zasłony grzechu pierworodnego. Tam jednak, gdzie docierało do ludzi przemieniało ich życie. W nim zaś najważniejsza była i jest miłośćn ${ }^{\prime \prime}$.

Por. Eklezjalne aspekty kultu świętych w nauce wspótczesnych teologów katolickich, „Studia Teologiczno-Dogmatyczne", t. 1, Warszawa 1974, s. 5-135.

4 E. Ozorowski, Personalizm chrześcijański, „Rocznik Teologii Katolickiej”, 4(2005), s. 10.

$5 \quad$ Ibidem, 11. Por. Idem, Miłość należy do definicji osoby". Ontyczne podstawy personalizmu, Małżenstwo i rodzina w zamyśle Bożym. Zarys problematyki, „Rocznik Teologii Katolickiej”, 3(2004) s. 9-18. 
Nasz Autor podkreśla też, że człowiek jest osobą od momentu swego poczęcia $^{6}$. Na jego wyjątkowość wskazuje przede wszystkim to, że jest on duszą i ciałem, osobą w naturze ludzkiej i że Bóg go powołuje do istnienia i daje mu siebie jako cel ostateczny ${ }^{7}$.

Prawdę o wielkości człowieka widzianego rozumem oświeconym wiarą przedstawia abp Ozorowski przy różnych okazjach. Warto w tym miejscu wspomnieć o inicjatywie powstałej we współpracy Katedry Teologii Katolickiej Uniwersytetu w Białymstoku, której założycielem i wieloletnim kierownikiem był abp Edward Ozorowski z Wyższą Szkołą Ekonomiczną w Białymstoku. Chodzi o cykl konferencji naukowych, na których wypowiadali się teologowie, etycy i ekonomiści. Pokłosiem tych konferencji były wydane książki o znamiennym tytule. Drugi i trzeci element tytułu niezmienny: etyka i ekonomia, pierwszym zaś zmienny: człowiek, małżeństwo, rodzina, kobieta, mężczyzna. Powstały $\mathrm{w}$ ten sposób cenne materiały naukowe, gdzie troska o człowieka, jako osoby była w centrum uwagi. Fundamentem, na bazie którego rozwijała się dalsza dyskusja podczas tych konferencji była zwykle wypowiedź abp. Ozorowskiego, który przypominał zasadnicze prawdy o człowieku, małżeństwie i rodzinie. Świadczą o tym tytuły referatów przez niego wygłaszanych: „Człowiek ważniejszy od rzeczy" (2001), „Nieprzemijająca wartość rodziny” (2005), „,Ontyczne podstawy małżeństwa” (2006), „Geniusz kobiety według Jana Pawła II” (2009), „Teologia ojcostwa” (2011).

Biskup Ozorowski stara się odpowiadać kim jest człowiek także w artykułach popularnonaukowych. Człowiek został stworzony „na obraz i podobieństwo Boże" (Rdz 1, 26), co sugeruje jego wyjątkowość na tle świata i wielką godność. Od przypomnienia tej prawdy rozpoczyna swój artykuł Godność człowieka z serii Co katolik wiedzieć powinien?8.

Arcybiskup Ozorowski akcentuje te myśli jako zrozumiałe dla chrześcijanina przesłanie wiary, a dla każdego człowieka myślącego jako logiczną konsekwencję przyjętego założenia. Ten wniosek chrystologiczny, stoi też u podstaw innych wypowiedzi Biskupa Profesora, a dotyczących miejsca i roli Maryi, Matki Jezusa i godności kobiety w jej różnych wymiarach życiowego powołania. W klimacie nieraz czysto ambicjonalnych. a nie merytorycznych przejaskrawien w poglądach na rolę kobiety w społeczeństwie, Ksiądz Profesor stara się oprzeć spojrzenie na wartość kobiety w świetle nauki chrześcijańskiej. Jakkolwiek rozpatruje jej godność kobiecą i macierzyńską w relacji do osoby Maryi, Matki

Por. E. Ozorowski, Małżeństwo jako komunia osób, „Studia Teologiczne Białystok - Drohiczyn - Łomża“ 20(2000), s. 31-52.

7 Idem, Człowiek droga Kościoła, [w:] A. Skreczko, D. Wojtecki red., W służbie człowiekowi, Białystok 2005, s. 12. [11-19].

$8 \quad$ Por. W. Guzewicz, Koncepcja człowieka jako osoby w prasie diecezjalnej Polski pótnocno-wschodniej po 1989 r., "Studia Teologiczne Białystok - Drohiczyn - Łomża“, s. 30(2012), s. 293-309. 
Jezusa, to podstawa teologiczna tej godności tkwi w akcie powołania człowieka do istnienia na zasadzie równości mężczyzny i kobiety9.

Autor obrazu kobiety jako żony i matki ukazuje w nauczaniu Jana Pawła II pewnego rodzaju odrodzenie idei powołania kobiety do rzeczywistości, w jakiej Bóg pragnie ją widzieć. Moment stworzenia człowieka, w wydaniu mężczyzny i kobiety, na „obraz" Boga, stanowi podstawę pełnej godności kobiety.

Idea obrazu Bożego w człowieku staje się w Piśmie Świętym, w teologii i w nauce Kościoła kryterium szczególnej, wręcz świętej godności osoby ludzkiej. Na tym kryterium opiera się także nauka o godności kobiety i jej równości $\mathrm{z}$ mężczyzną.

Kościół w swojej nauce o wielkości kobiecego powołania odwołuje się do osoby Maryi, Matki Jezusa, jako szczególnego wzoru każdej kobiety. Niektóre ruchy feministyczne odrzucają tego rodzaju wzór nie uznając motywów chrześcijańskich i wartości proponowanych przez Chrystusa. Dla chrześcijańskiej kobiety są to jednak podstawy wypływające z wiary i do nich to właśnie odwołuje się abp E. Ozorowski w swojej refleksji.

W podobny sposób do pogłębionej wiary i płynących z niej konsekwencji dla ludzkiego życia, odnosi się Autor zajmując się zagadnieniem świętości. Wydaje się, że zainteresowanie kultem świętych, a zwłaszcza męczenników, wypływa u naszego Profesora zarówno z potrzeb intelektualnych, osobistych przeżyć rodzinnych, jak również duszpasterskich. Okazuje się bowiem, że ta problematyka podjęta już w jego rozprawie doktorskiej stała się aktualna duszpastersko u Profesora jako Biskupa, który pragnie utrwalić w historii i w życiu wiernych pamięć o męczennikach tych stron Rzeczypospolitej i Kościoła ${ }^{10}$.

W parze z troską o wiarę i świętość człowieka zawartą w twórczości Biskupa, płynie jego humanistyczny rys charakteru, jakim jest pamięć i wdzięczność wobec ludzi, którzy wnieśli swoją działalnością poważny kapitał duchowy i kulturowy w życie konkretnych osób i społeczeństwa. O tym świadczą między innymi opublikowane teksty Profesora: Pamięć wdzięczności początkiem. O ludziach mi bliskich (Białystok 1995), i seria biogramów teologów polskich, zawartych w Stowniku polskich teologów katolickich (Warszawa 1981-1985). Należy w tym fakcie uznać wewnętrzną cechę wrażliwości i poczucia odpowiedzialności Teologa i Biskupa za strzeżenie skarbca myśli i kultury ludzi Kościoła, którzy swoją aktywnością myślową ubogacali także kulturę własnego narodu.

$9 \quad$ Por. E. Ozorowski, Maryjny rys godności kobiety jako matki w nauce Jana Pawła II, WKAB 9 (2000) nr 2 s. 83-100; Idem, Maryja wzorem ucznia Chrystusowego, „Studia Teologiczne Białystok - Drohiczyn Łomża“ 21(2003), s. 31-39.

10 Por. idem, Wielorakie znaczenie męczenników, „Studia Teologiczne Białystok - Drohiczyn - Łomża“ 17(1999), s. 41-54; Idem, Męczennicy - jasne promienie XX wieku. Homilia wygłoszona podczas Mszy św. na terenie byłego obozu koncentracyjnego Gross Rosen. Rogoźnica 05.09.1999, [w:] Z otchłani obozu Gross-Rosen świadectwo nadziei, Legnica 2001, s. 100-1004; Idem, Kult męczenników w Archidiecezji Białostockiej, Białystok 2000 


\section{Małżeństwo i rodzina}

Punktem wyjścia do analizy nauczania abp. Ozorowskiego na temat małżeństwa i rodziny mogą być słowa Papieża Jana Pawła II wypowiedziane 27 sierpnia 1999 roku do uczestników Tygodnia Studiów nad Małżeństwem i Rodziną odbywającego się w Rzymie w Instytucie Studiów nad Rodziną przy Lateranie: „refleksja nad zamysłem Bożym wobec człowieka, małżeństwa i rodziny to zadanie, które będziecie musieli podjąć $\mathrm{z}$ nową energią na początku trzeciego tysiąclecia“. To zadanie podjął już wcześniej Arcybiskup Ozorowski z nową energią, rozpoczynając w 1992 roku pracę dydaktyczną w Instytucie Studiów nad Rodziną w Łomiankach (UKSW) i podejmując znaczące inicjatywy wydawnicze. Już podjęcie pracy na tym kierunku świadczy o tym, że widział on „ducha czasu“ i coraz większą potrzebę pogłębionej refleksji teologicznej związanej z małżeństwem i rodziną. Arcybiskup Edward Ozorowski podjął nauczanie w Instytucie założonym przez abp. Kazimierza Majdańskiego, który wiele serca i trudu włożył w rozwój nauk o rodzinie. Wielkim dziełem życia abp. Majdańskiego było wypełnienie votum złożonego jako więzień obozu w Dachau: stworzenia i rozwoju Instytutu Studiów nad Rodziną. Pisał dużo na temat małżeństwa i rodziny, zebrał też pionierski zespół naukowców, który podjął się kontynuacji wielkiego zadania obrony i promocji małżeństwa i rodziny. Ksiądz abp E. Ozorowski stał się jedną z ważniejszych postaci w tym Instytucie.

Szybko rozwijająca się nowa specjalność, jaką jest wiedza o rodzinie, wymagała kompendialnego ujęcia nagromadzonych wyników badań i aktualnego stanu. Naprzeciw tej potrzebie wyszedł Słownik Małżeństwa i Rodziny, którego redaktorem był bp E. Ozorowski. Nauki o rodzinie, podobnie jak każdy nowo kształtujący się przedmiot, posiadają charakter wybitnie interdyscyplinarny i to tym bardziej przemawiało za koniecznością zebrania i usystematyzowania tego, co do tych nauk wnoszą: teologia, filozofia, psychologia, pedagogika, medycyna, socjologia i prawo.

Słownik Małżeństwa i Rodziny redagowany przez doświadczonego Teologa zawiera zbiór haseł rzeczowych, dotyczących podstawowych, ale szeroko ujętych wiadomości o małżeństwie i rodzinie. Zgromadzony materiał definiuje pojęcia małżeństwa i rodziny w obrębie szerokiego wachlarza dyscyplin. Połączenie dwóch nurtów: teologiczno-filozoficznego i przyrodniczego w opracowaniu problematyki małżeństwa i rodziny stanowi oryginalny i niezwykle wartościowy walor poznawczy, nawet dla odbiorców dalekich od scalania aspektów duchowego, przyrodniczego i społecznego w studiach nad małżeństwem i rodziną. Chociaż Słownik jest adresowany głównie do czytelników zajmujących się zawodowo lub naukowo sprawami rodziny, to jednak fakt ogromnej atrakcyjności i aktualności prezentowanej tematyki czyni pracę interesującą również dla przygodnych, ale z pasją poznawczą czytelników. Ranga i aktualność problematyki rodzinnej, zwłaszcza rozpatrywana $\mathrm{w}$ aspekcie wielodyscyplinarnym, stawia omawiane dzieło $\mathrm{w}$ rzędzie prac najbardziej potrzebnych, wręcz 
koniecznych, zaś forma encyklopedyczna czyni Słownik Małżeństwa i Rodziny niezwykle atrakcyjnym i wartościowym. Warto podkreślić, że tam również zostało zamieszczonych 40 haseł dotyczących problematyki małżeńskiej i rodzinnej w opracowaniu abp. prof. E. Ozorowskiego. Zasadniczo są to krótkie artykuły naukowe, napisane według standardów metodologicznych z podaniem podstawowej literatury przedmiotu.

Niedługo po wydaniu omawianego Słownika, Autor podjął się redakcji kolejnego obszernego dzieła: Bibliografii małżeństwa i rodziny 1945-198911. Nie było to zadanie łatwe. Jak pisze we Wstępie do tego opracowania:

rodzina bowiem jest rzeczywistością, która wchodzi we wszystkie obszary życia. Stąd też niemal wszystko, co pisze się o człowieku, odnosi się także wprost lub pośrednio do rodziny. W „Bibliografii" starano się zamieścić te pozycje, które wprost dotyczą rodziny, ze świadomością oczywiście, że sąd selektora jest względny ${ }^{12}$.

Większość prac, związanych z bibliografią przypadła w udziale pracownikom Instytutu Studiów nad Rodziną, ale bez dobrego selekcjonera ich praca byłaby chaotyczna.

Od początku swojej pracy dydaktycznej w Instytucie Studiów nad Rodziną w Łomiankach abp Ozorowski spojrzenie na małżeństwo i rodzinę ukazywał w licznych publikacjach oraz całościowo przedstawił w książce Małżeństwo i rodzina w zamyśle Bożym ${ }^{13}$. Stanowią one ciąg dalszy refleksji antropologicznej, gdzie zamysł Boży odgrywa zasadniczą rolę. Już we Wstępie do swojej książki zauważa, że

pierwotna wiedza człowieka i późniejsze nauki, dotyczące małżeństwa i rodziny, mają do czynienia z rzeczywistością zastaną, zbudowaną według niezwykle misteryjnego planu. (...) Małżeństwa i rodziny szczęśliwe potwierdzają istnienie pierwotnego planu, który nimi rządzi ${ }^{14}$.

A ponieważ samo pojęcie "zamysłu Bożego" nie zawsze jest poprawnie rozumiane, dalej we Wstępie znajdujemy jego dokładne omówienie. Następnie Autor odnosi je do małżeństwa i rodziny twierdząc, że

zamysł Boży, tak jak mówi nam o nim Objawienie, znajduje się u początków małżeństwa i rodziny. (...) Widziane w jego świetle małżeństwo i rodzina należą do porządku stworzenia, są rzeczywistością pierwotną i posiadają swoje nienaruszalne, określone przez Boga zasady ${ }^{15}$.

Następuje dalej związanie tej tematyki z wiedzą o człowieku, jakby upomnienie się o godność człowieka:

\footnotetext{
Warszawa, UKSW, 2005, ss. 635.

Ibidem, s. 7.

Warszawa 2009, UKSW, ss. 313.

Ibidem, s. 2-3.

Ibidem, s. 11 .
} 
idąc drogą zamysłu Bożego, odkrywamy, że małżeństwo i rodzinę tworzą ludzie. Jest to prawda tak oczywista, że wielu jej nie widzi, nie pamięta o niej, lekceważy ją lub nią gardzi. Człowiek - to ogromnie dużo. Posiada on swoją godność. Jest obrazem Boga i nosi w sobie podobieństwo do Boga ${ }^{16}$.

Porządek stworzenia odnosi się zarazem do relacji mężczyzny i kobiety. Został jednak zakłócony przez grzech pierwszych rodziców, który położył się cieniem na małżeństwie i rodzinie. Jednak przez Wcielenie Bóg uszanował człowieka, jak też miłość małżeńską, która dzięki temu może rozbłysnąć nowym światłem. Syn Boży przyjął ciało z Maryi i wzrastał w rodzinie. Jak wzniośle w tym kontekście brzmi zdanie naszego Autora: „Rodzina, dzięki temu stała się drogą, po której Bóg zstępuje do ludzi, i po której ludzie wznoszą się do Boga"17.

W Chrystusie zamysł Boży osiągnął swój cel. Biskup jednak przestrzega, aby ci, którzy chcą żyć według zamysłu Bożego wystrzegali się pomyłek w jego rozumieniu. Nie mogą utożsamiać go ze ślepym losem. Biblia mówi zawsze o Bogu żywym, który pozostaje wierny swemu zamysłowi i kieruje się miłością a nie o ślepej, bezdusznej sile rządzącej światem. Trzeba go odczytywać z wiarą. Jednak nie wolno zapominać, że odczytywanie zamysłu Bożego nie jest monopolem osób wierzących. Zamysł Boży odnosi się bowiem do wszystkich ludzi.

Trzecim porządkiem, oprócz stworzenia i Wcielenia, na który wskazuje abp Ozorowski jest porządek celu ostatecznego. Jest on dany i zadany przez Boga. Jest rzeczywistością istniejącą obiektywnie, niezależnie od tego, czy człowiek ją akceptuje, czy odrzuca. Teoria celu ostatecznego funkcjonuje właściwie, gdy przenika człowieka i wywołuje w nim coraz to nowe pytania ostateczne. Istotną sprawą jest to, aby znajdowały one adekwatną odpowiedź w Chrystusie. Arcybiskup przenosi to zagadnienie na rzeczywistość małżeństwa i rodziny i stawia pytanie: „co przetrwa z tego, co na ziemi stanowi rzeczywistość małżeństwa i rodziny? Pierwsza odpowiedź nasuwa się spontanicznie: przetrwają ludzie. Czy przetrwają jako małżonkowie i rodzina?"18. Rzeczywistość małżeństwa istnieje przecież nie tylko jako środek do celu, lecz także jako cel sam w sobie, inicjowany na ziemi i osiągnięty w niebie. Eschatyczny wymiar małżeństwa wynika z samej istoty tegoż małżeństwa, to znaczy z miłości. Małżeństwo jest symbolem wiecznych zaślubin Chrystusa z odkupioną ludzkością i znakiem eschatycznej nadziei.

Poszukując odpowiedzi na pytanie o eschatyczny wymiar małżeństwa nasz Autor stwierdza, że „komunia małżeńska w niebie osiągnie stan finalny. Realizowana na ziemi istnieje w stanie grzechu pierworodnego, będzie w niebie wyzwolona ze zmazy grzechu pierworodnego"19. Przypuszczalnie więc, będzie miała znaczenie po śmierci.

\footnotetext{
$16 \quad$ Ibidem.

17 Ibidem, s. 13.

18 Ibidem, s. 266.

19 Ibidem, s. 267.
} 
Niewiele mówi o wymiarze eschatycznym rodziny w omawianej książce Biskup Teolog. Wskazuje za to na Świętą Rodzinę, nazywając ją „ikoną ludzkich rodzin"20. Święta Rodzina już tu na ziemi zanurzona była w wieczności. Istotne wydaje się być stwierdzenie, że „podobnie jak miarą człowieczeństwa jest stopień zbliżenia lub oddalenia od Boga, tak również ojcostwo i synostwo doznają uwznioślenia przez zacieśnienie więzów z Bogiem”21.

\section{Zakończenie}

Najlepszą syntezą tej krótkiej analizy poglądów abp. Ozorowskiego o człowieku, małżeństwie i rodzinie mogą być słowa soborowego dokumentu Gaudium et spes: „tajemnica człowieka wyjaśnia się naprawdę dopiero w tajemnicy Słowa Wcielonego" (n. 22). Z wszystkich tekstów Arcybiskupa wyłania się obraz osoby ludzkiej, która jest czymś jedynym, wyjątkowym, niepowtarzalnym, obrazem samego Boga. Obraz z kolei z zasady oddaje istotę swego pierwowzoru. Dlatego istnienie człowieka nie ma sensu poza Bogiem.

Warto jednocześnie zauważyć, że wszelka refleksja naukowa zawarta w tak licznych opracowaniach zdaje się wypływać z osobistej głębokiej wiary naszego Teologa i jego poczucia odpowiedzialności za duchową formację chrześcijanina.

W jego dorobku naukowym znajdziemy przekrój wielu zagadnień teologicznych i dogmatycznych. Zasadniczo prawie wszystkie domeny teologiczne zostały przez niego w ten lub inny sposób poruszone. Niewątpliwie przewijają się liczne wątki związane z Kościołem, mariologią i Eucharystią, ale również antropologią oraz małżeństwem i rodziną. Widzimy, że jest on autorem wszechstronnym, dogłębnie starającym się przedstawić podejmowane tematy, bazując na Biblii, nauczaniu kościelnym, jak też myśli znanych teologów i przedstawicieli innych nauk.

\section{Bibliografia}

Guzewicz W., Koncepcja człowieka jako osoby w prasie diecezjalnej Polski północno-wschodniej po 1989 r., „Studia Teologiczne Białystok - Drohiczyn - Łomża“ 2012.

Ozorowski E., Bibliografia małżeństwa i rodziny 1945-1989, Warszawa, 2005.

Ozorowski E., Człowiek droga Kościoła, [w:] A. Skreczko, D. Wojtecki red., W służbie człowiekowi, Białystok 2005.

Ozorowski E., Eklezjalne aspekty kultu świętych w nauce wspótczesnych teologów katolickich, "Studia Teologiczno-Dogmatyczne”, t. 1, Warszawa 1974.

Ozorowski E., Eucharystia w nauce i praktyce Kościoła Katolickiego, Poznań 1990.

\footnotetext{
$20 \quad$ Ibidem, s. 269.

21 Tbidem.
} 
Ozorowski E., Kościót. Zarys eklezjologii katolickiej, Wrocław 1984.

Ozorowski E., Kult męczenników w Archidiecezji Białostockiej, Białystok 2000.

Ozorowski E., Maryja wzorem ucznia Chrystusowego, „Studia Teologiczne Białystok Drohiczyn - Łomża“ 21(2003).

Ozorowski E., Maryjny rys godności kobiety jako matki w nauce Jana Pawła II, WKAB 9 (2000) nr 2.

Ozorowski E., Małżeństwo i rodzina w zamyśle Bożym, Warszawa 2009.

Ozorowski E., Małżeństwo jako komunia osób, „Studia Teologiczne Białystok - Drohiczyn - Łomża“ 20(2000).

Ozorowski E., Miłość należy do definicji osoby". Ontyczne podstawy personalizmu, Małżeństwo i rodzina w zamyśle Bożym. Zarys problematyki, „Rocznik Teologii Katolickiej", 3(2004).

Ozorowski E., Męczennicy - jasne promienie XX wieku. Homilia wygłoszona podczas Mszy św. na terenie byłego obozu koncentracyjnego Gross Rosen. Rogoźnica 05.09.1999, [w:] Z otchłani obozu Gross-Rosen świadectwo nadziei, Legnica 2001.

Ozorowski E., Personalizm chrześcijański, „Rocznik Teologii Katolickiej”, 4(2005)

Ozorowski E., Piotrowe dziedzictwo. Rozważania majowe, Białystok 1991.

Ozorowski E., Wielorakie znaczenie męczenników, „Studia Teologiczne Białystok - Drohiczyn - Łomża“ 17(1999). 